\title{
CP-82,009, A POTENT POLYETHER ANTICOCCIDIAL RELATED TO SEPTAMYCIN AND PRODUCED BY Actinomadura sp.
}

\author{
John P. Dirlam ${ }^{\dagger}$, Annette M. Belton, Jon Bordner, Walter P. Cullen, liang H. Huang, \\ Yasuhiro Kojma $^{\dagger \dagger}$, Hiroshi Maeda ${ }^{\dagger \dagger}$, Satoshi Nishiyama ${ }^{\dagger \dagger}$, John R. Oscarson, \\ Anthony P. Ricketts, Tatsuo SaKakibara ${ }^{\dagger \dagger}$, Junsuke TONE ${ }^{\dagger \dagger}$, \\ Katsuhtsu Tsukuda ${ }^{\dagger \dagger}$ and Mamoru Yamada ${ }^{\dagger \dagger}$ \\ Central Research Division, Pfizer Inc., \\ Groton, CT 06340, U.S.A. \\ ${ }^{\dagger+}$ Taketoyo, Aichi 470-23, Japan
}

(Received for publication October 21, 1991)

\begin{abstract}
A new polyether antibiotic CP-82,009 $\left(\mathrm{C}_{49} \mathrm{H}_{84} \mathrm{O}_{17}\right)$ was isolated by solvent extraction from the fermentation broth of Actinomadura sp. (ATCC 53676). Following purification by column chromatography and crystallization, the structure of CP-82,009 was elucidated by spectroscopic (NMR and MS) methods. The absolute stereochemistry was determined by a single crystal X-ray analysis of the corresponding rubidium salt. CP-82,009 is among the most potent anticoccidial agents known, effectively controlling the Eimeria species that are the major causative agents of chicken coccidiosis at doses of $5 \mathrm{mg} / \mathrm{kg}$ or less in feed. It is also active in vitro against certain Gram-positive bacteria, as well as the spirochete, Serpulina (Treponema) hyodysenteriae.
\end{abstract}

Polyether antibiotics have been an important class of drugs in veterinary medicine for over 20 years. For example, monensin ${ }^{1)}$, lasalocid ${ }^{1)}$ and salinomycin ${ }^{2)}$ are marketed as anticoccidal agents for poultry, and are used as growth permittants in cattle and swine. Narasin ${ }^{1)}$ and maduramicin ${ }^{3)}$ are also used as anticoccidial agents.

In the course of screening actinomycetes for novel antimicrobial substances, a new strain of Actinomadura sp. was found to produce a new polyether antibiotic, CP-82,009 (1). This compound, which was very potent against Eimeria coccidia in chickens, was shown to be structurally similar to septamycin ${ }^{4)}$. The present paper describes the taxonomy and fermentation studies on the producing organism of CP-82,009, as well as the isolation, characterization and biological testing of this antibiotic ${ }^{5)}$.

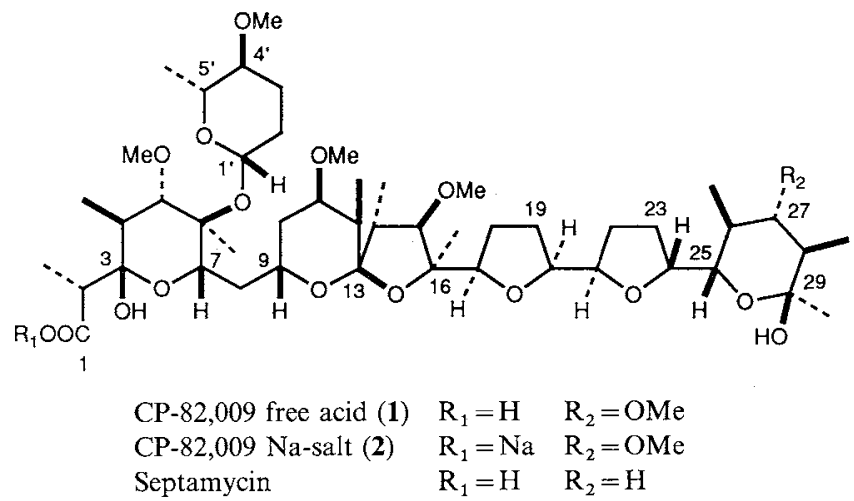

$\dagger$ Presented in part at the 13th International Congress of Heterocyclic Chemistry, Abstract No. GE12-135, Corvallis, Oregon, August $11 \sim 16,1991$. 


\section{Taxonomy of the Producing Strain}

The CP-82,009 producing strain, Actinomadura sp. N742-34, was isolated from a soil sample collected in Hongo Town, Toyama City, Toyama Prefecture, Japan. It was found to have narrow hyphae of the actinomycetes, an aerial mycelium upon which spore chains are produced, and an unfragmented substrate mycelium. The culture is further characterized by the white to pale gray aerial mycelium; the green-yellow, yellow-brown to brown substrate mycelium; and the short straight to flexuous spore chains with a warty surface (Figs. 1 and 2). However, the culture did not produce spores on any media except for inorganic salts - starch agar. After seven weeks of incubation on this medium, a few small patches of spore chains were produced. They were short with 3 to 9 spores per spore chain and were straight, flexuous, curved to hooked. The spores were globose, oval to elliptical and measured $0.9 \sim 1.3 \mu \mathrm{m}$ diameter or $1.0 \sim 1.6 \times 0.8 \sim 1.1 \mu \mathrm{m}$, respectively. The physiological properties and carbohydrate utilization are shown in Tables 1 and 2. The whole-cell hydrolysates indicate the presence of meso-diaminopimelic acid, madurose, glucose, galactose and ribose. Thus, the culture belongs in the genus Actinomadura, as defined by

Fig. 1. Scanning electron micrograph of a cluster of short spore chains of Actinomadura sp. ATCC 53676 grown on inorganic salts - starch agar for seven weeks at $28^{\circ} \mathrm{C}, \times 9,000$.

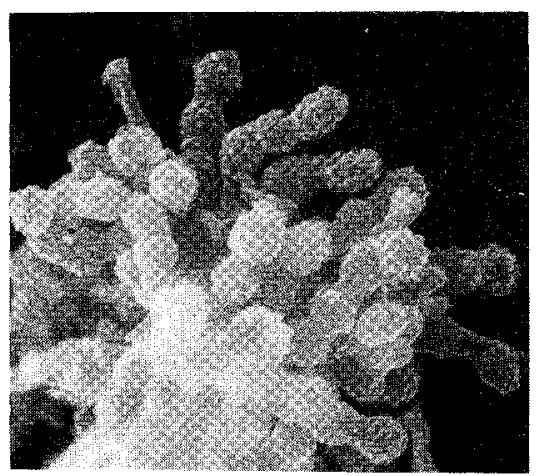

Fig. 2. Scanning electron micrograph of a spore chain of Actinomadura sp. ATCC 53676 grown on inorganic salts - starch agar for seven weeks at $28^{\circ} \mathrm{C}, \times 10,000$.

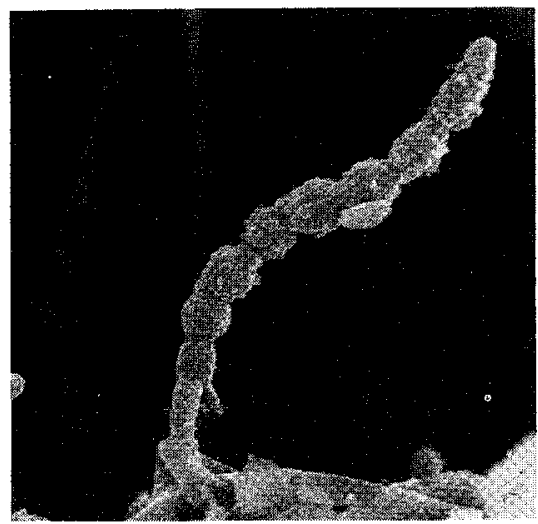

Note a short sporophore at the base of the spore chain and the warty nature of the spore surface.
Table 1. Physiological properties of Actinomadura sp. N742-34.

\begin{tabular}{ll|ll}
\hline Production of: & & Resistance to: & \\
Gelatinase & + & Lysozyme & - \\
Melaninase & - & Reduction of: & \\
Tyrosinase & + & Organic nitrate & - \\
Urease & - & Dextrose nitrate & + \\
$\mathrm{H}_{2} \mathrm{~S}$ & - & Utilization of: & \\
Milk: & & Acetate & + \\
Coagulation & + & Propionate & + \\
Clearing & + & Pyruvate & + \\
Decomposition of: & & Growth at: & \\
Adenine & - & $21^{\circ} \mathrm{C}$ & + \\
Cellulose & - & $28^{\circ} \mathrm{C}$ & + \\
Esculin & - & $37^{\circ} \mathrm{C}$ & + \\
Hippurate & - & $45^{\circ} \mathrm{C}$ & - \\
Hydrolysis of: & & & \\
Casein & + & & \\
Hypoxanthine & - & & \\
Starch & + & & \\
Xanthine & - & & \\
\hline
\end{tabular}

Table 2. Carbohydrate utilization of Actinomadura sp. N742-34.

\begin{tabular}{ll|ll}
\hline Adonitol & - & $\alpha$-Methyl-D & - \\
Arabinose & - & glucoside & \\
Cellobiose & - & Melezitose & - \\
Dulcitol & - & Melibiose & - \\
Erythritol & - & Raffinose & - \\
Fructose & - & Rhamnose & + \\
Galactose & - & Ribose & - \\
Glucose & + & Salicin & - \\
Glycerol & - & Sorbitol & - \\
Inositol & - & Sorbose & - \\
Lactose & - & Starch & + \\
Maltose & - & Sucrose & + \\
Mannitol & - & Trehalose & + \\
Mannose & - & Xylose & - \\
\hline
\end{tabular}




\section{LECHEVALIER ${ }^{6)}$.}

Growth was good on yeast extract - malt extract agar, BENNETT's agar, EMERSON's agar, and GAUZE's organic medium 2; moderate to good on oatmeal agar, CZAPEK - sucrose agar, glucose - asparagine agar, GORDON and SMITH's tyrosine agar, casein agar, gelatin agar, starch agar, and GAUZE's mineral medium 1; poor on inorganic salts - starch agar, nutrient agar, glycerol - asparagine agar, potato carrot agar, and tap water agar; and none on calcium malate agar.

Aerial mycelium was generally none or sparse and colorless or white to pale gray. The surface color of the colonies was yellowish green $(1 \mathrm{ic})^{7)}$ on most media used, cream on CZAPEK - sucrose agar $(11 / 2 \mathrm{ca})$, and brown ( 3 ne) on starch agar. The reverse color of the colonies was yellowish to yellowish brown ( 2 ga, 3 lc) on most of the media used, colorless to cream (11/2 ca) on CZAPEK - sucrose agar, and brown (3le) on gelatin agar. The soluble pigment was generally lacking; yellowish (2lc) on yeast extract - malt extract agar, GoRdon and SMITH's tyrosine agar, and BENNETT's agar; yellowish brown (3 lc) on casein agar and EMERSON's agar; and pale cream (1 1/2 ca) on GAUZE's mineral medium 1.

Among the more than forty species of Actinomadura, five resemble strain N742-34 in morphological and/or biochemical properties: A. citrea, A. cremea, A. flava, A. livida, and A. macra. Both A. citrea and A. flava produce a lemon-yellow substrate mycelium, as does strain N742-34. A. flava produces long spore chains and spores with a smooth surface, whereas strain N742-34 forms short spore chains and spores with a warty surface. Unlike strain N742-34, A. citrea utilizes arabinose, xylose, mannitol, and fructose.

A. livida forms spore chains in the form of hooks or spirals with a single turn, whereas strain N742-34 forms straight or flexuous spore chains. On oatmeal and GAUZE's mineral medium 1, A. livida forms a pale violet soluble pigment, but strain N742-34 forms a cream soluble pigment.

A. cremea differs from strain N742-34 in positive utilization of arabinose, fructose, mannitol, xylose, adonitol, glycerol, lactate, and succinate; negative utilization of sucrose and starch; and decomposition of esculin.

A. macra is closely similar to strain N742-34 in most of the biochemical properties. A few differences were noted. Unlike the former, the latter utilizes rhamnose and starch, coagulates milk, and decomposes casein. In addition, strain N742-34 produces mostly a yellow-green, yellow-brown or brown substrate mycelium and spores with a warty surface; whereas $A$. macra produces mostiy a cream or gray substrate mycelium and spores with a smooth surface.

On the basis of the above, strain N742-34 is considered as a member of the genus Actinomadura and designated Actinomadura sp. It has been deposited at the American Type Culture Collection under the accession No. ATCC 53676.

\section{Fermentation}

Actinomadura sp. ATCC 53676 was maintained on an ATCC 172 medium (g/liter: glucose (10), soluble starch (20), yeast extract (5), NZ-Amine A (1), calcium carbonate (1) and agar (20); pH 7.0 (with KOH) for $7 \sim 9$ days at $28^{\circ} \mathrm{C}$ ), and the inoculum was grown in JDYTT medium (g/liter: Cerelose (10), corn starch (5), corn steep liquor (5), NZ-Amine YTT (5), cobalt chloride (0.002) and calcium carbonate (3); pH 7.2 for $5 \sim 7$ days at $\left.28 \sim 36^{\circ} \mathrm{C} ; 150 \sim 200 \mathrm{rpm}\right)$. A $3 \%$-inoculum was used to seed a production run in $\mathrm{C}^{\prime}$ medium (g/liter: Cerelose (10), corn starch (10), soybean flour (10), corn fermentable solids (5), sodium chloride (5), cobalt chloride (0.002) and calcium carbonate (1); pH 7.2 for $5 \sim 7$ days at $30^{\circ} \mathrm{C} ; 1,700 \mathrm{rpm}$ (jar), $600 \mathrm{rpm}(\operatorname{tanks})$ ). The antibiotic titers were followed by using a dise assay on a sensitive strain of 
Bacillus subtilis ATCC 6633 . The presence of CP-82,009 was followed by TLC on silica gel plates using ethyl acetate as the eluent. The ionophore was visualized as a rose-red coloration using vanillin - $\mathrm{EtOH}-\mathrm{H}_{3} \mathrm{PO}_{4}$ spray reagent ( $3 \mathrm{~g}$ vanillin in $75 \mathrm{ml}$ of $\mathrm{EtOH}$ and $25 \mathrm{ml}$ of $85 \% \mathrm{H}_{3} \mathrm{PO}_{4}$ ), followed by heating to $80^{\circ} \mathrm{C}$.

\section{Isolation}

Work-up of a tank fermentation of whole broth was carried out by extracting the approximately 100 liters of broth with 50 liters of methyl isobutyl ketone. The organic extract was separated, and concentrated in vacuo. The resulting oil was chromatographed on $500 \mathrm{~g}$ of silica gel using ethyl acetate. The active cuts were combined and then concentrated in vacuo, dissolved in ethyl acetate, treated with Darco G60 and filtered. The filtered solution was shaken first with phosphoric acid, then with $\mathrm{pH} 9.0$ sodium phosphate buffer to form the sodium salt. After drying over anhydrous $\mathrm{Na}_{2} \mathrm{SO}_{4}$, the solvent was concentrated in vacuo, and the resulting product was crystallized from ethyl acetate - heptane to afford $0.95 \mathrm{~g}$ of CP-82,009 Na-salt (2). Further purification was accomplished by flash chromatography using a column of $100 \mathrm{~g}$ of silica gel, $32 \sim 63 \mu \mathrm{m}$, and employing a gradient of $95: 5$ to $50: 50$ chloroform - ethyl acetate, and $0.85 \mathrm{~g}$ of product as 2 was obtained following the removal of solvent in vacuo.

\section{Structural Determination}

CP-82,009 free acid (1) was obtained by treatment of a chloroform solution of the sodium salt 2 with an aqueous solution of $\mathrm{HCl}$. CP-82,009 Rb-salt was prepared from the free acid 1 , and the resulting crystals were suitable for X-ray crystallographic studies (see below). The physico-chemical properties of the free acid 1 and its sodium salt 2 are summarized in Table 3 .

Spectroscopic data and elemental analyses were consistent with $\mathrm{C}_{49} \mathrm{H}_{84} \mathrm{O}_{17}$ for the free acid 1 , and $\mathrm{C}_{49} \mathrm{H}_{83} \mathrm{O}_{17} \mathrm{Na}$ for the sodium salt 2 . For example, in the positive FAB-MS, diagnostic cationized molecules $m / z 967\left((\mathrm{M}+\mathrm{Na})^{+}\right)$and $989\left((\mathrm{M}+2 \mathrm{Na}-\mathrm{H})^{+}\right)$were detected for 2. Furthermore, 2 gave a base peak at $m / z$ 905, i.e., 62 daltons less than the corresponding metal-adduct molecular ion, which is common for polyethers having a $\beta$-hemiketal carboxylic acid group $\left(\left(\mathrm{M}+\mathrm{Na}-\mathrm{CO}_{2}-\mathrm{H}_{2} \mathrm{O}\right)^{+}\right)^{8)}$. The ${ }^{13} \mathrm{C}$ and ${ }^{1} \mathrm{H} \mathrm{NMR}$ spectral data for 2 , including a polarization transfer (DEPT) ${ }^{9)}$ experiment revealed the following groups. $\mathrm{CH}_{3}$ (10), $\mathrm{CH}_{2}$ (8), $\mathrm{CH}(6), \mathrm{CH}_{3} \mathrm{O}(5), \mathrm{O}-\mathrm{CH}(13), \mathrm{C}-\mathrm{O}(2), \mathrm{O}-\mathrm{CH}-\mathrm{O}(1), \mathrm{O}-\mathrm{C}-\mathrm{O}(3)$, and $-\mathrm{COONa}$ (1) (see Table 4). These groups accounted for all the hydrogens in 2 except for two exchangeable ones,

Table 3. Physico-chemical properties of CP-82,009 free acid (1) and Na-salt (2).

\begin{tabular}{lll}
\hline \multicolumn{1}{c}{ Property } & \multicolumn{1}{c}{1} & \multicolumn{1}{c}{2} \\
\hline $\mathrm{MP}\left({ }^{\circ} \mathrm{C}\right)$ & $95 \sim 102$ & $175 \sim 177$ \\
{$[\alpha]_{\mathrm{D}}^{25}(c 1.0, \mathrm{MeOH})$} & $+20.2^{\circ}$ & $+12.8^{\circ}$ \\
Empirical formula & $\mathrm{C}_{49} \mathrm{H}_{84} \mathrm{O}_{17}$ & $\mathrm{C}_{49} \mathrm{H}_{83} \mathrm{O}_{17} \mathrm{Na}$ \\
$\mathrm{MW}$ & 945.2 & 967.2 \\
Elemental analysis & $\mathrm{C}_{49} \mathrm{H}_{84} \mathrm{O}_{17} \cdot \mathrm{H}_{2} \mathrm{O}$ & $\mathrm{C}_{49} \mathrm{H}_{83} \mathrm{O}_{17} \mathrm{Na} \cdot \mathrm{H}_{2} \mathrm{O}$ \\
Calcd: & $\mathrm{C} 61.10, \mathrm{H} 9.00$ & $\mathrm{C} 59.74, \mathrm{H} 8.70$ \\
Found: & $\mathrm{C} 61.53, \mathrm{H} \mathrm{9.31}$ & $\mathrm{C} 59.47, \mathrm{H} 8.54$ \\
IR (CHCl $\left.{ }_{3}\right)$ & $3414,2928,2876,2828,1675$ & $2926,2829,1599\left(-\mathrm{CO}_{2} \mathrm{Na}\right)$, \\
& $\left(-\mathrm{CO}{ }_{2} \mathrm{H}\right), 1457,1378,1287$, & $1458,1378,1163,1086,976$ \\
Solubility & $1163,1089,1054,953$ & \\
Soluble: & & \\
Insoluble: & Organic solvents & Organic solvents \\
\hline
\end{tabular}


Table 4. ${ }^{13} \mathrm{C}$ and ${ }^{1} \mathrm{H}$ NMR chemical shift data for the Na-salts of $\mathrm{CP}-82,009$ and septamycin in $\mathrm{CDCl}_{3}$.

\begin{tabular}{|c|c|c|c|c|}
\hline \multirow{2}{*}{ Carbon } & \multicolumn{2}{|c|}{ CP- 82,009} & \multicolumn{2}{|c|}{ Septamycin ${ }^{a}$} \\
\hline & ${ }^{13} \mathrm{C}$ shift ${ }^{b}$ & ${ }^{1} \mathrm{H}$ shift ${ }^{\mathrm{c}}$ & ${ }^{13} \mathrm{C}$ shift ${ }^{\mathrm{b}}$ & ${ }^{1} \mathrm{H}$ shift ${ }^{\mathrm{c}}$ \\
\hline $1 \mathrm{COONa}$ & $180.77(0)$ & - & $180.5(0)$ & - \\
\hline $2 \mathrm{CH}$ & $45.22(1)$ & 2.41 & 45.4 (1) & 2.47 \\
\hline $3 \mathrm{O}-\mathrm{C}-\mathrm{O}$ & $99.62(0)$ & - & $99.5(0)$ & - \\
\hline $4 \mathrm{CH}$ & $40.71(1)$ & 1.73 & $40.7(1)$ & 1.76 \\
\hline $5 \mathrm{O}-\mathrm{CH}$ & $88.79(1)$ & 3.29 & $88.7(1)$ & 3.34 \\
\hline $6 \mathrm{C}-\mathrm{O}$ & $80.25(0)$ & - & $80.2(0)$ & - \\
\hline $7 \mathrm{O}-\mathrm{CH}$ & $67.54(1)$ & 3.75 & $67.4(1)$ & 3.79 \\
\hline $8 \mathrm{CH}_{2}$ & $32.53(2)$ & $1.43,1.72$ & $32.5(2)$ & $1.48,1.78$ \\
\hline $9 \mathrm{O}-\mathrm{CH}$ & $61.57(1)$ & 3.95 & $61.5(1)$ & 3.99 \\
\hline $10 \mathrm{CH}_{2}$ & $31.13(2)$ & $1.13,2.12$ & $31.1(2)$ & $1.16,2.15$ \\
\hline $11 \mathrm{O}-\mathrm{CH}$ & $79.75(1)$ & 3.32 & $79.6(1)$ & 3.35 \\
\hline $12 \mathrm{CH}$ & $36.92(1)$ & 1.74 & $36.9(1)$ & 1.76 \\
\hline $13 \mathrm{O}-\mathrm{C}-\mathrm{O}$ & $106.70(0)$ & - & $106.6(0)$ & - \\
\hline $14 \mathrm{CH}$ & $46.13(1)$ & 2.07 & $46.0(1)$ & 2.12 \\
\hline $15 \mathrm{O}-\mathrm{CH}$ & $94.74(1)$ & 3.51 & $94.7(1)$ & 3.54 \\
\hline $16 \mathrm{C}-\mathrm{O}$ & $83.26(0)$ & - & $83.2(0)$ & - \\
\hline $17 \mathrm{O}-\mathrm{CH}$ & $79.06(1)$ & 3.87 & $79.1(1)^{\mathrm{d}}$ & 3.92 \\
\hline $18 \mathrm{CH}_{2}$ & $25.63(2)$ & $1.75,1.88$ & $25.6(2)$ & $1.77,1.93$ \\
\hline $19 \mathrm{CH}_{2}$ & $23.01(2)$ & 1.70 & $23.0(2)$ & 1.72 \\
\hline $20 \mathrm{O}-\mathrm{CH}$ & $79.30(1)$ & 4.31 & $79.2(1)^{\mathrm{e}}$ & 4.56 \\
\hline $21 \mathrm{O}-\mathrm{CH}$ & $83.49(1)$ & 3.66 & $83.3(1)^{\mathrm{f}}$ & 3.70 \\
\hline $22 \mathrm{CH}_{2}$ & $29.18(2)$ & $1.37,1.92$ & $29.2(2)$ & $1.38,1.93$ \\
\hline $23 \mathrm{CH}_{2}$ & $24.17(2)$ & $1.79,2.11$ & $24.2(2)$ & $1.80,2.16$ \\
\hline $24 \mathrm{O}-\mathrm{CH}$ & $80.25(1)$ & 4.30 & $80.4(1)$ & 4.30 \\
\hline $25 \mathrm{O}-\mathrm{CH}$ & $73.95(1)$ & 3.85 & $75.4(1)$ & 3.82 \\
\hline $26 \mathrm{CH}$ & $39.41(1)$ & 1.25 & $32.7(1)$ & 1.32 \\
\hline $27 \mathrm{O}-\mathrm{CH} / \mathrm{CH}_{2}$ & $84.70(1)$ & 2.90 & $36.8(2)$ & 1.48 \\
\hline $28 \mathrm{CH}$ & $46.32(1)$ & 1.38 & $39.6(2)$ & —g \\
\hline $290-C-O$ & $98.40(0)$ & - & $96.8(0)$ & - \\
\hline 2-Me & $11.54(3)$ & 1.01 & $11.5(3)$ & 1.06 \\
\hline 4-Me & $12.00(3)$ & 0.98 & $12.0(3)$ & 1.01 \\
\hline 5-OMe & $61.72(1)$ & 3.51 & $61.2(3)$ & $3.54^{\mathrm{h}}$ \\
\hline 6-Me & $9.95(3)$ & 1.18 & $9.9(3)$ & 1.22 \\
\hline $11-\mathrm{OMe}$ & $58.94(3)$ & 3.41 & $58.9(3)$ & $3.47^{\mathrm{h}}$ \\
\hline $12-\mathrm{Me}$ & $12.54(3)$ & 1.02 & $12.6(3)$ & 0.98 \\
\hline $14-\mathrm{Me}$ & $11.51(3)$ & 0.96 & $11.5(3)$ & 1.00 \\
\hline $15-\mathrm{OMe}$ & $60.18(3)$ & 3.37 & $60.1(3)$ & $3.41^{\mathrm{h}}$ \\
\hline $16-\mathrm{Me}$ & $28.43(3)$ & 1.58 & $28.4(3)$ & 1.62 \\
\hline 26-Me & $13.14(3)$ & 0.91 & $17.3(3)$ & 0.82 \\
\hline $27-\mathrm{OMe}$ & $59.93(3)$ & 3.40 & - & - \\
\hline $28-\mathrm{Me}$ & $12.69(3)$ & 0.94 & $16.9(3)$ & 0.90 \\
\hline $29-\mathrm{Me}$ & $26.58(3)$ & 1.26 & $26.4(3)$ & 1.28 \\
\hline \multicolumn{5}{|c|}{ Deoxysugar $(\text { Deo })^{\mathrm{i}}$} \\
\hline $\mathrm{l}^{\prime} \mathrm{O}-\mathrm{CH}-\mathrm{O}$ & $96.63(1)$ & 4.81 & $96.5(1)$ & 4.86 \\
\hline $2^{\prime} \mathrm{CH}_{2}$ & $31.90(2)$ & $1.54,1.78$ & $31.8(2)$ & $1.55,1.84$ \\
\hline $3^{\prime} \mathrm{CH}_{2}$ & $27.69(2)$ & $1.32,2.18$ & $27.7(2)$ & $1.32,2.22$ \\
\hline $4^{\prime} \mathrm{O}-\mathrm{CH}$ & $80.25(1)$ & 2.78 & $80.2(1)$ & 2.81 \\
\hline $5^{\prime} \mathrm{O}-\mathrm{CH}$ & $74.33(1)$ & 3.28 & $74.3(1)$ & 3.33 \\
\hline $4^{\prime}-\mathrm{OMe}$ & $56.82(3)$ & 3.31 & $56.8(3)$ & $3.35^{\mathrm{h}}$ \\
\hline $5^{\prime}-\mathrm{Me}$ & $18.54(3)$ & 1.23 & $18.5(3)$ & 1.26 \\
\hline
\end{tabular}

a Assignments are based on ref 13 .

b In ppm from TMS in $\mathrm{CDCl}_{3}$ solution; number of attached protons are in parentheses.

c In ppm from TMS in $\mathrm{CDCl}_{3}$ solution.

d Originally assigned C-20 in ref 13 .

e Originally assigned $\mathrm{C}-21$ in ref 13 .

f Originally assigned $\mathrm{C}-17$ in ref 13 .

$\mathrm{g}$ Not ascertained in ref 13 .

h Tentatively assigned in ref 13 and may be interchanged.

i 4-Methylamicetose. 
which were assumed to be free hydroxy functions on $\delta_{\mathrm{C}} 99.62$ and 98.40 based on deuterium induced upfield shifts observed in the ${ }^{13} \mathrm{C}$ NMR spectrum of 2 (see Experimental). Both the $\delta_{\mathrm{C}} 99.62$ and 98.40 were assigned as hemiketal carbons, and $\delta_{\mathrm{C}} 106.70$ to a ketal carbon by process of elimination.

In our efforts to elucidate the structures of unknown ionophores, we have found that it is helpful to estimate the number of rings $(R)$ and the number of oxygen links (E). This is done by the NMR method developed by WHIPPLE et al. ${ }^{10)}$, and we have previously illustrated its use for another ionophore ${ }^{11)}$, i.e., CP-84,657. In the present case, where there are three exchangeable protons (including $\mathrm{Na}^{+}$for the sodium salt 2 ), the estimated number of rings (R) is 7, and the number of oxygen links (E) is 13 for 2 .

With a knowledge of $\mathrm{R}, \mathrm{E}$, and the empirical formula of CP-82,009, coupled with other information such as the presence of one ketal and two hemiketal functions, and a sugar moiety, a comparison with known polyether antibiotics can be readily made. Indeed, among the known ionophores, CP-82,009 is similar to a group of antibiotics designated "group 3b" by SETO and $\bar{O}_{\text {TAKE }}{ }^{12)}$, namely, etheromycin (CP-38,295), A204A, carriomycin, septamycin, 6016, K-41A, and K-41B. In particular, CP-82,009 is closely related to septamycin. A comparison of the ${ }^{13} \mathrm{C}$ and ${ }^{1} \mathrm{H}$ NMR chemical shifts for $\mathrm{CP}-82,009$ Na-salt (2) (obtained by using ${ }^{13} \mathrm{C}$ DEPT, COSY, HETCOR experiments in a previously described manner ${ }^{11)}$ ) with those values reported for the sodium salt of septamycin (A28695A) ${ }^{13)}$ is shown in Table 4. Many of the ${ }^{13} \mathrm{C}$ and ${ }^{1} \mathrm{H}$ signals of 2 essentially correspond to those of septamycin Na-salt. However, some marked changes in the ${ }^{13} \mathrm{C}$ chemical shifts between the two polyethers were observed that are centered at $\mathrm{C}-27$, which is consistent with the addition of a methoxy group at $\mathrm{C}-27$ in $\mathbf{2}$. The structure elucidated for $\mathbf{2}$ based on NMR studies, i.e., 27-methoxyseptamycin, was confirmed by the $\mathrm{X}$-ray analysis of the corresponding $\mathrm{Rb}$-salt as discussed below.

\section{X-Ray Analysis of CP-82,009 Rb-salt}

The three-dimentional structure of the rubidium salt to 1 was determined by $\mathrm{X}$-ray crystallography with a crystal that measured $0.14 \times 0.14 \times 0.19 \mathrm{~mm}$. A $1 \AA$ data set (maximum $\sin \theta / \lambda=0.5$ ) was collected on a Nicolet $\mathrm{R} 3 \mathrm{~m} / \mu$ diffractometer, and trial structure was obtained by direct methods revealing the following lattice parameters: $a=15.646(4) \AA, b=15.646(3) \AA$ and $c=50.32(1) \AA$ with $\alpha=90.0^{\circ}, \beta=90.0^{\circ}$ and $\gamma=90.0^{\circ}$. The space group was determined to be $\mathrm{P}_{3} 2_{1} 2$ with 8 molecules per unit cell. The molecular formula was $\mathrm{C}_{49} \mathrm{H}_{83} \mathrm{O}_{17} \mathrm{Rb}$ with a calculated density of $1.11 \mathrm{~g} / \mathrm{cm}^{3}$. There were 3,701 reflections collected, and of those reflections $2,519(68 \%)$ with $\mathrm{I}>3.0 \sigma$ were adjudged observed. This trial structure refined routinely. Hydrogens were calculated wherever possible. The methyl hydrogens and the hydrogens on 
Fig. 4. Crystal structure of CP-82,009 Rb-salt.

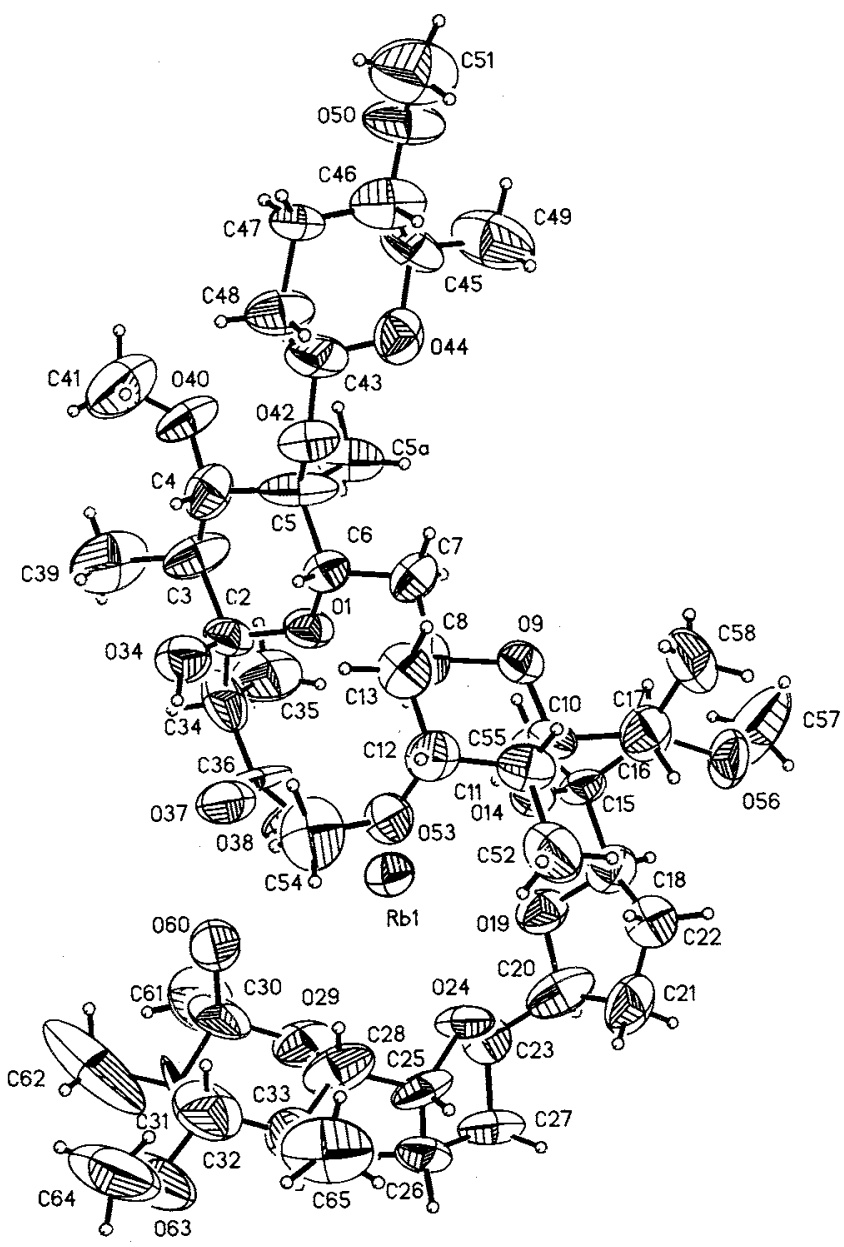

oxygen were located by difference Fourier techniques. The hydrogen on oxygen 60 could not be located satisfactorily. The hydrogen parameters were added to the structure factor calculations but were not refined. The shifts calculated in the final cycle of least-squares refinement were all less than 0.1 of their corresponding standard deviations. The final R-index was 0.095. A final difference Fourier revealed no missing or misplaced electron density. The rubidium ion was used to establish the absolute configuration utilizing the method of IBERS and HAMILTON ${ }^{14)}$, and HAMILTON ${ }^{15}$.

The computer generated perspective drawing of the final X-ray model of $\mathrm{CP}-82,009 \mathrm{Rb}$-salt is shown in Fig. 4. The anion of the ionophore is wrapped around the central metal ion in a fashion typical of complexed ionophores, generating a number of short $\mathrm{Rb}-\mathrm{O}$ bond distances. With the exception of the additional methoxy group at $\mathrm{C}_{27}$, the absolute configuration determined for $\mathrm{CP}-82,009 \mathrm{Rb}$-salt is the same as that reported for the parent strucrure septamycin, as established by $\mathrm{X}$-ray crystal structure analysis of the $p$-bromophenacyl derivative ${ }^{4)}$.

\section{Biological Activity}

CP-82,009 is among the most potent ionophores known in terms of anticoccidial activity. We conducted anticoccidial efficacy titrations against five major pathogenic species of poultry coccidia, with salinomycin 
Table 5. Anticoccidial activity of CP-82,009, salinomycin and maduramicin in chickens ${ }^{\mathrm{a}}$.

\begin{tabular}{|c|c|c|c|c|c|c|c|c|c|c|c|}
\hline \multirow[t]{2}{*}{ Treatment } & \multirow{2}{*}{$\begin{array}{c}\text { Dose } \\
(\mathrm{mg} / \mathrm{kg})\end{array}$} & \multicolumn{2}{|c|}{$\begin{array}{c}\text { Eimeria } \\
\text { tenella }\end{array}$} & \multicolumn{2}{|c|}{$\begin{array}{l}\text { Eimeria } \\
\text { necatrix }\end{array}$} & \multicolumn{2}{|c|}{$\begin{array}{c}\text { Eimeria } \\
\text { acervulina }\end{array}$} & \multicolumn{2}{|c|}{$\begin{array}{l}\text { Eimeria } \\
\text { maxima }\end{array}$} & \multicolumn{2}{|c|}{$\begin{array}{l}\text { Eimeria } \\
\text { brunetti }\end{array}$} \\
\hline & & $\% \mathrm{WG}$ & $\% \mathrm{LC}$ & $\% \mathrm{WG}$ & $\% \mathrm{LC}$ & $\% \mathrm{WG}$ & $\% \mathrm{LC}$ & $\% W G$ & $\% \mathrm{LC}$ & $\% W G$ & $\%$ LC \\
\hline $\begin{array}{l}\text { Uninfected, } \\
\text { untreated }\end{array}$ & 0 & 100 & 100 & 100 & 100 & 100 & 100 & 100 & 100 & 100 & 100 \\
\hline $\begin{array}{l}\text { Infected, } \\
\text { untreated }\end{array}$ & 0 & 64 & $(3.8)^{\mathrm{b}}$ & 49 & (3.1) & 75 & (3.2) & 54 & $(2.8)$ & 44 & (2.9) \\
\hline \multirow[t]{3}{*}{ CP-82,009 } & 10 & 80 & 100 & 86 & 100 & 69 & 100 & 83 & 97 & 80 & 93 \\
\hline & 5 & 98 & 100 & 94 & 100 & 89 & 94 & 77 & 84 & 82 & 52 \\
\hline & 2.5 & 107 & 79 & 91 & 79 & 90 & 67 & 86 & 69 & 63 & 17 \\
\hline Salinomycin & 60 & 95 & 92 & 76 & 100 & 93 & 91 & 71 & 93 & 95 & 87 \\
\hline Maduramicin & 5 & 83 & 92 & 96 & 100 & 103 & 94 & 87 & 100 & 95 & 100 \\
\hline
\end{tabular}

Abbreviations: WG, weight gain; LC, lesion control.

a Data are averages for $2 \sim 4$ tests.

b Lesion score, maximum of 4.0 for all species.

and maduramicin as positive controls (Table 5). CP-82,009 exhibited broad spectrum efficacy and toleration, comparable to commercial controls, at doses of 5 or $10 \mathrm{mg} / \mathrm{kg}$ in feed. Substantial efficacy was seen against most species at a $2.5 \mathrm{mg} / \mathrm{kg}$ dose. CP-82,009 appeared to have potency similar to maduramicin and CP-84,657 (12-methylportmicin), and superior to four other commercial anticoccidial ionophores (i.e., salinomycin, narasin, lasalocid and monensin), when compared in the same test system $^{11)}$. We do not have comparable data for the parent structure septamycin, however, published information ${ }^{16)}$ would indicate that $\mathrm{CP}-82,009$ is $c a$. 6 times more potent than septamycin.

The results of the in vitro antibacterial testing of CP-82,009 are summarized in Table 6. In general, polyether antibiotics are highly effective against Gram-positive bacteria and a number of anaerobic bacteria, but exhibit no activity against Gram-negative aerobes. Activity versus Serpulina (Treponema) hyodysenteriae, a causative agent in swine dysentery, is often observed. CP-82,009 does in fact exhibit the expected excellent activity against a number of Gram-positive bacteria, as well as the spirochete, S. hyodysenteriae. No activity was observed versus Escherichia coli, Salmonella choleraesuis and Actinobacillus (Haemophilus) pleuropneumoniae.

\section{Experimental}

General Methods

The media for characterization of the culture and some biochemical tests are those used by HUANG ${ }^{17)}$. The utilization of organic acid; the acid production from carbohydrates; the hydrolysis of hippurate and esculin; the resistance to lysozyme; and the decomposition of adenine, hypoxanthine, xanthine, and urea are those described by GoRDon et al. ${ }^{18)}$. The methods of whole-cell amino acid and sugar analyses were described by BECKer et al. ${ }^{19)}$ and by LeCHEVALIER ${ }^{6)}$. 
MP's were determined on a Thomas-Hoover capillary apparatus and are uncorrected. Spectral data were recorded on the following instruments: NMR, Bruker WM-250 spectrometer (modified to incorporate a pulse programmer and Aspect-3000 data system) and a Bruker AM-500 spectrometer, using $50 \mathrm{mg}$ samples dissolved in $0.5 \mathrm{ml}$ of $\mathrm{CDCl}_{3}$ (spectra were recorded at $24^{\circ} \mathrm{C}$ ); IR, Perkin-Elmer 1420 spectrophotometer, FAB-MS, VG Analytical 70/250-S mass spectrometer in the positive ion mode using a dithiothreitol - dithioerythritol (3:1) matrix; and optical rotations, Perkin-Elmer 141 polarimeter.

Isotope shift measurements for 2 in $\mathrm{CDCl}_{3}$ solution consisted of identically measuring the ${ }^{13} \mathrm{C}$ spectrum following successive washes with $\mathrm{H}_{2} \mathrm{O}-\mathrm{D}_{2} \mathrm{O}(1: 1), \mathrm{H}_{2} \mathrm{O}$ and finally $\mathrm{D}_{2} \mathrm{O}$. In the latter two instances, the washes were repeated several times prior to recording the ${ }^{13} \mathrm{C}$ spectrum.

\section{CP-82,009 Na-salt}

The sodium salt of $\mathrm{CP}-82,009$ was obtained as described above from fermentation. The physico-chemical properties are given in Table $3 .{ }^{13} \mathrm{C}$ and ${ }^{1} \mathrm{H}$ NMR chemical shift data (in $\mathrm{CDCl}_{3}$ ) and assignments are summarized in Table 4.

\section{CP-82,009 Free Acid}

The free acid of $\mathrm{CP}-82,009$ was prepared by vigorously shaking a $\mathrm{CHCl}_{3}$ solution of the corresponding sodium salt with an equal volume of $\mathrm{HCl}$ at $\mathrm{pH} 2$ in a separatory funnel. The phases were separated, and the $\mathrm{CHCl}_{3}$ layer was washed with water and then evaporated under vacuum to give the free acid (Table 3 ).

\section{CP-82,009 K-salt}

To prepare the potassium salt of $\mathrm{CP}-82,009$, the free acid $(229 \mathrm{mg})$ was dissolved in $\mathrm{CHCl}_{3}(100 \mathrm{ml})$. Potassium carbonate $(75 \mathrm{mg})$ in $100 \mathrm{ml}$ of water was added and the resulting mixture was allowed to stir for 15 minutes and was then placed in a separatory funnel and vigorously shaken for several minutes. The organic phase was separated and evaporated under vacuum to afford $\mathrm{CP}-82,009 \mathrm{~K}$-salt as a white solid; $\mathrm{mp} 175 \sim 179^{\circ} \mathrm{C},[\alpha]_{\mathrm{D}}^{25}+13.8^{\circ}(c 1.0, \mathrm{MeOH}) .{ }^{1} \mathrm{H}$ and ${ }^{13} \mathrm{C}$ NMR spectra were consistent with the desired structure.

$\begin{array}{ll}\text { Anal Calcd for } \mathrm{C}_{49} \mathrm{H}_{83} \mathrm{O}_{17} \mathrm{~K} \cdot \mathrm{H}_{2} \mathrm{O}: & \mathrm{C} 58.78, \mathrm{H} 8.56 . \\ \text { Found: } & \text { C } 59.17, \mathrm{H} 8.89 .\end{array}$

\section{CP-82,009 Rb-salt}

To prepare the rubidium salt of $\mathrm{CP}-82,009$, the free acid $(100 \mathrm{mg})$ was dissolved in $\mathrm{CHCl}_{3}(100 \mathrm{ml})$. Rubidium carbonate $\left(150 \mathrm{mg}\right.$ in $100 \mathrm{ml}$ of water) was added to the $\mathrm{CHCl}_{3}$ solution and the mixture was shaken vigorously in a separatory funnel for several minutes. The organic phase was separated and extracted one time with deionized, distilled water, and then evaporated to afford a white solid. The rubidium salt was recrystallized by slow evaporation from ether and used directly for single crystal X-ray analysis.

\section{Single Crystal X-Ray Analysis of CP-82,009 Rb-salt}

The refined structure was plotted using the SHELXTL ${ }^{20)}$ plotting package (Fig. 4). Coordinates, anisotropic temperature factors, distances and angles are available as supplementary material.

Anticoccidial and Antimicrobial Assays

Anticoccidial testing was conducted according to CHAPPEL et al. ${ }^{21)}$, using the lesion scoring system of JoHNSON and REID ${ }^{22)}$ for all species.

MICs were determined as described by DiRlam et al. ${ }^{23)}$ except that all anaerobes were tested on Tryptose Agar (Difco) supplemented with $5 \%$ bovine blood (TBA) and incubated 48 hours at $39^{\circ} \mathrm{C}$ in a Coy (Ann Arbor, Mich.) anaerobe chamber containing an $\mathrm{N}_{2}-\mathrm{CO}_{2}-\mathrm{H}_{2}(80: 10: 10)$ atmosphere. MICs for aerobes were determined in an identical manner except that Brain-Heart Infusion Agar (Difco) was used, and plates were incubated aerobically at $37^{\circ} \mathrm{C}$ for $18 \sim 20$ hours.

\section{Acknowledgments}

The authors are grateful to Dr. E. B. WhiPPle and Ms. D. M. ResceK for NMR spectral data, and Dr. J. G. STROH 
for FAB-MS. We thank Mr. C. P. CoRnell for the antimicrobial assays and Ms. D. M. NewcomB and Mr. J. W. HARGIS (Pfizer Animal Health, Terre Haute, IN) for conducting the anticoccidial studies.

\section{References}

1) Ruff, M. D.: Chaper 6. Veterinary applications. In Polyether Antibiotics. Naturally Occurring Acid Ionophores. Volume 1: Biology. Ed., J. W. WestLey, pp. 303 332, Marcell Dekker, Inc., 1982

2) Miyazaki, Y.; M. Shibuya, H. Sugawara, O. Kawaguchi, C. Hirose, J. Nagatsu \& S. Esumi: Salinomycin, a new polyether antibiotic. J. Antibiotics 27: 814 821, 1974

3) Pento, J. T.: Maduramicin. Drugs Future 12: 756 757, 1987

4) Keller-Juslén, C.; H. D. King, Z. L. Kis \& A. von Wartburg: Septamycin, a polyether antibiotic. Taxonomy, fermentation, isolation, and characterization. J. Antibiotics 28: 854 859, 1975

5) Dirlam, J. P.; W. P. Cullen, H. Maeda \& J. Tone (Pfizer): An acidic polycyclic ether useful as an anticoccidial agent and as a growth promotant. Eur. Pat. Appl. 317 231, May 24, 1989

6) LeChevalier, M. P.: Identification of aerobic actinomycetes of clinical importance. J. Lab. Clin. Med. 71: 934 944, 1968

7) Color Harmony Manual. 4th Ed., Container Corporation of America, 1958

8) Siegel, M. M.; W. J. MCGahren, K. B. Tomer \& T. T. Chang: Applications of fast atom bombardment mass spectrometry and fast atom bombardment mass spectrometry-mass spectrometry to the maduramicins and other polyether antibiotics. Biomed. Environ. Mass Spectrom. 14: 29 38, 1987

9) Doddrell, D. M.; D. T. Pegg \& M. R. Bendall: Distortionless enhancement of NMR signals by polarization transfer. J. Magn. Reson. 48: 323 327, 1982

10) Bordner, J.; P. C. Watts \& E. B. Whipple: Structure of the natural antibiotic ionophore CP-54,883. J. Antibiotics 40: $1496 \sim 1505,1987$

11) Dirlam, J. P.; A. M. Belton, J. Bordner, W. P. Cullen, L. H. Huang, Y. Kojima, H. Maeda, H. Nishida, S. Nishryama, J. R. Oscarson, A. P. Ricketts, T. Sakakibara, J. Tone \& K. Tsukuda: CP-84,657, a potent polyether anticoccidial related to portmicin and produced by Actinomadura sp. J. Antibiotics 43: 668 679, 1990

12) H. Seto \& N. OTAKe: Chapter $6 .{ }^{13} \mathrm{C}$ NMR spectra of polyether antibiotics. In Polyether Antibiotics. Naturally Occurring Acid Ionophores. Volume 2: Chemistry. Ed., J. W. WeSTLEY, pp. $335 \sim 400$, Marcell Dekker, Inc., 1983

13) Dorman, D. E.; R. L. Hamill, J. L. Occolowitz, Y. Terui, K. Tori \& N. Tsuil: Structure of polyether antibiotic A28695B. J. Antibiotics 33: 252 255, 1980

14) IBERs, J. \& W. C. HAmilton: Dispersion corrections and crystal structure refinements. Acta Cryst. 17: 781 782, 1964

15) Hamilton, W. C.: Significant tests on the crystallographic R factor. Acta Cryst. 18: 502 510, 1965

16) Meingassner, J. G.; J. Hildebrandt, R. Leskova \& H. Mieth: Laboratory studies on the anticoccidial activity of septamycin. Poultry Sci. 56: $1281 \sim 1288,1977$

17) Huang, L. H.: Actinomadura macra sp. nov., the producer of antibiotics CP-47,433 and CP-47,434. Int. J. Syst. Bacteriol. 30: $565 \sim 568,1980$

18) Gordon, R. E.; D. A. Barnett, J. E. Handerhan \& C. H. Pang: Nocardia coeliaca, Nocardia autotrophica, and the nocardicin strain. Int. J. Syst. Bacteriol. 24: 54 63, 1974

19) Becker, B.; M. P. Lechevalier, R. E. Gordon \& H. A. Lechevalier: Rapid differentiation between Nocardia and Streptomyces by paper chromatography of whole-cell hydrolysates. Appl. Microbiol, 12: 421 423, 1964

20) Sheldrick, G. M.: SHELXTL User Manual. Nicolet Instrument Co., 1981

21) Chappel, L. R.; H. L. Howes \& J. E. LyNCH: The site of action of a broad-spectrum aryltriazine anticoccidial, CP-25,415. J. Parasitol. 60: 415 420, 1974

22) Johnson, J. \& W. M. Reid: Anticoccidial drugs. Lesion scoring techniques in battery and floor pen experiments in chicks. Exp. Parasitol. 28: 30 36, 1970

23) Dirlam, J. P.; L. J. Czuba, B. W. Dominy, R. B. James, R. M. Pezzullo, J. E. Presslitz \& W. W. Windisch Synthesis and antibacterial activity of 1-hydroxy-1-methyl-1,3-dihydrofuro[3,4-b]quinoxaline 4,9-dioxide and related compounds. J. Med. Chem. 22: 1118 121, 1979 